\title{
THE APPEARANCE OF THE QUEBI TABOO METHOD WITH A REFLECTION ON USING BIHUI TO EXAMINE CHINESE SOURCES
}

\author{
SUN JIANQIANG \\ Centre for the Study of Religion, Leiden University \\ P.O. Box 9515, NL-2300 RA Leiden, the Netherlands \\ e-mail: j.sun@hum.leidenuniv.nl
}

\begin{abstract}
Although it has been traditionally accepted that quebi 缺筆, one of the name taboo (bihui 避諱) methods, appeared in Tang Gaozong's reign (649-683), a number of unexamined examples attest that quebi may have appeared in Tang Taizong's reign (626-649). This advancement enhances the usage of bihui to conduct research and urges us to rethink the 7th-century development of bihui.
\end{abstract}

Key words: bihui, taboo method, quebi, Tang Gaozong, Tang Taizong.

\section{Introduction}

Bihui or name taboo was an enduring ancient Chinese tradition which forbade users to write and speak the names of gods, ancestors, emperors and even enemies and so on. One of the most common taboo methods, quebi, has been believed to be invented in Tang Gaozong's reign, since Chen Yuan 陳垣, a noted Chinese scholar, first systematically examined bihui in 1928 in his essay, Shihui juli 史諱舉例, “the framework" of the field which "is regarded even today as a standard work" (Adamek 2015, pp. 12-13; Chen Yuan 1928, 1958). ${ }^{1}$ Despite the 90 -years consensus, however, this traditional theory can be refuted on several grounds.

Below, this paper first introduces the traditional argument. It then demonstrates that the quebi method was used earlier than the alleged first quebi examples. Our paper relies on two examples which are dated to 648 and advances that quebi first

${ }^{1}$ This paper refers to Chen Yuan's book published in 1958. For more evaluations of Chen Yuan's contribution, see Zhu Luchuan (2015) and Zhang Hengjun (2003). 
appeared in Tang Taizong's reign. The paper concludes with discussions of the usefulness of this advancement.

\section{Appearance in Tang Gaozong's Reign}

In the writing of Chinese characters, the term quebi means to omit the strokes of characters - usually the last stroke. For example, 世 and $¥$. The former is the orthodox orthography of $s h i$ 世. The latter lacks the last stroke, the long bottom horizontal line, and occurs in Dunhuang manuscript P.2536 which bears the date 663 (Dou Huaiyong 2010, p. 139). ${ }^{2}$ It was written in that particular 'wrong' orthography in order to avoid shi, the first character contained in Tang Taizong's name, shimin 世民. ${ }^{3}$

This particular method to avoid names, according to Chen Yuan, appeared in the mid-7th century, and the principal argument rests upon the earliest examples. Chen Yuan argues that the earlier examples are ambiguous whereas the 7 th-century illustrations are clear and ample. As his first indisputable illustrations are found in stones that were carved in Tang Gaozong's reign and bear the date 666, Chen Yuan specifies that quebi “must have started in Tang Gaozong's reign” (當起於唐高宗之 世) (Chen Yuan 1958, p. 7). These alleged earliest examples have been recently reconfirmed by Adamek who paraphrases the term quebi as 'the method of a missing stroke' (Adamek 2015, p. 145, sic.): ${ }^{4}$

In the inscription of “Zengtai shikong xuangongbei” 贈泰師孔宣公碑 (Stone Stele Presented to the Greatest Teacher Confucius) from 666, the character $\min$ 泯 is written as $z h i$ 汦. The case is regarded as the first known example of the method of a missing stroke. Similar instances can also be found in the "Zhining bei" 志寧碑 (Stone Stele of Zhining, 666) $-s h i$ 世 is written as $s a$ 井 in the expression shiwu 世武, and on the “Li He bei" 李賀碑 (Stone Stele of Li He) (677) - there is the $s a$ 井 character put in place of $s h i$ 世 in the name of Wang Shichong 王世充.

\section{Quebi around 660}

The following decree preserved in Tanghuiyao attests that quebi had been used around 660 for some time. According to the decree, Tang Gaozong intended to curb the excessive taboo of his name, zhi 治 (Wang Pu 961/1955, p. 452) ${ }^{5}$ :

${ }^{2}$ This manuscript will be revisited below.

${ }^{3}$ For more quebi examples of this character, see Adamek (2015, pp. 54-55, 145), Michel Soymié (1990, pp. 388-389, 404), and Dou Huaiyong (2010, pp. 225-226).

${ }^{4}$ The very first source should be transcribed as Zeng taishi kongxuangong bei. The full Chinese title of “Zhining bei” should be Yu Zhining bei 于志寧碑. The "Li He bei" should be the Li Ji bei 李漬碑.

${ }^{5}$ It has to be noted though that traditionalists including Chen Yuan have observed this. See Adamek (2015, p. 144) and Chen Yuan (1958, p. 7). 
On the first day of the first month in the fifth year of the Xianqing reign, it is decreed: "[...] When the ancient classics are copied, my name should either be omitted of strokes or replaced randomly by other characters. The meaning of elegant words of the six cannons, I am afraid, will be impacted. Should the versions be spread far and long, meanings will be changed completely. This is not the purpose of creating books. From now on, copying and editing old and canonic works shall be made in a convenient manner. There is no need to replace and modify [my name].” (顯慶五年正月一日詔。[...... 比見抄寫古典。至於朕名。 或缺其點畫。或隨便改換。恐六籍雅言。會意多爽。九流通 義。 指事全違。誠非立書之本。自今以後。繥寫舊典文字。並宜使 成。不須随義改易。)

Here, two implications interest us most. One is the pre-promulgation condition. According to the decree, taboo practice had already been very popular by 660 . People seemed fanatical about avoiding the ruling emperor's name zhi. Consequentially, many canonical texts were changed to such a degree that their original meanings were altered and their reading was impaired. Even the emperor himself was fairly disturbed by the extravagant practice.

The other implication is that Tang people were popularly using two taboo methods. One method was to replace $z h i$ with other characters (synonyms). This is a very old method. Tang Chinese just continued to use it. The popularity of this method can be confirmed by many phrases in which $z h i$ was substituted with synonyms. For example, the title of a 5th-century source, Zhixianpu 治縣譜, was renamed to Lixian$p u$ 理縣譜 in Nanshi 南史. In this case, both zhi and li mean 'govern' or 'administrate'. Nanshi is the official historical account of 4th- to 7th-century Chinese dynasties. It was compiled by Li Yanshou 李延壽 and submitted to Tang Gaozong who wrote a preface to it in 659. Understandably, Li Yanshou avoided the name of Tang Gaozong. ${ }^{6}$

The other method was quebi. Admittedly, Tang Gaozong neither used the very term, nor offered an example. However, there is little doubt that he was referring to the quebi method. The Chinese phrase “que qi dian hua" (缺其點畫) is straightforward. Each character is simple and unambiguous. Except for the reading of the quebi method, on the basis of their literal meaning 'lacking dots and strokes', there is no other way to interpret these four characters. In other words, quebi appeared earlier than the year 666. It had been used for some time before 660 .

\section{Pre-666 quebi Occurrences in Tang Gaozong's Reign}

The following examples exhibit that the above so-called earliest quebi examples are not even the first usage of quebi in Tang Gaozong's reign.

\footnotetext{
${ }^{6}$ For more similar examples, see Adamek (2015, p. 245), Wang Jian (2011, pp. 266-267), and Wang Yankun (2009, pp. 406-413).
} 
Dou Huaiyong discovered a number of quebi examples used in 663. His examples are found in the above-mentioned manuscript P.2536. In this source, the last

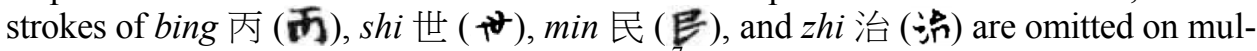
tiple occasions (Dou Huaiyong 2010, p. 139).

However, these examples are still two decades later than the following example that I found by accident. The example, 治, occurs in a straightforward phrase "zhiren" (治人, govern people) used by Zhou Zhongyin zhi 周仲隱誌 or Zhou Zhongyin's tombstone inscription. ${ }^{8}$ Compared with the orthodox form, this example lacks the last two strokes. Unquestionably, it is one of the quebi taboos of Tang Gaozong's name, zhi.

According to the inscription, Zhou Zhongyin had a successful career and was bestowed with high titles by the court. He died on "the twentieth day of the first month, in the twenty-third year of the Zhenguan reign” (貞觀廿三年正月廿日， March 8th, 649) and was buried tenth months later in Luoyang, on "the twenty-fifth day of the tenth month" (十月廿五日, December 4th, 649) (Ibid.). ${ }^{9}$ On the evidence of this dating, our example appears to be earlier than any other known quebi taboos of $z h i$. It demonstrates that quebi was already used no later than the year 649 .

\section{The Introduction of quebi in Tang Taizong's Reign}

In fact, Zhou Zhongyin's tombstone inscription already suggests that quebi might have appeared in Tang Taizong's reign. Zhou Zhongyin died in March. Tang Taizong passed away in July. Conceivably, Zhou Zhongyin's family might have carved the tombstone before Tang Taizong's death and buried it on the funeral in December.

In addition to this possibility, these two examples, 愿 and $\mathscr{F}$, are unequivocal. They are the earliest quebi occurrences I have found. Although they are hardly mentioned by many taboo experts, the following five reasons strongly point to the conclusion that they are $h u$ 虎 (虎) that lacks the last vertical stroke. The purpose of employing these two examples was to avoid the name of $\mathrm{Li} \mathrm{Hu}$ 李虎 $(?-551)$, the grandfather of Li Yuan 李淵 who created the Tang dynasty 唐朝 in 618 .

The first reason is that the source is genuine. The two examples occur in Shanjianl $\ddot{u}$ 善見律, a Tang Buddhist manuscript famous for its exquisite calligraphy (23 centimetres $\times 457$ centimetres). As shown below, its production information is clear. The manuscript was produced by the Tang court. Most likely, it was once used by Emperor Tang Taizong. Moreover, as attested by private seals and historical notes, this manuscript had been the property of the elite Chinese throughout history. For some time it was kept in the imperial library and was examined by several emperors

\footnotetext{
${ }^{7}$ I have re-examined each example by downloading manuscript images from the website of the International Dunhuang Project, http://idp.bl.uk/. All websites referred to in this paper were retrieved on July 5th, 2017.

${ }^{8}$ The example is found in Column 30 of the Beijing tushuguan jinshizu (1997, p. 200).

${ }^{9}$ All the Chinese dates used in this paper are transferred into the Western calendar via the Sino-Western Calendar Transfer Program offered by Academia Sinica at http://sinocal.sinica.edu.tw.
} 
of different dynasties. Currently, it is housed at the Palace Museum 故宮博物院 in Beijing. ${ }^{10}$

The second reason is that the context reveals that the two examples are the character $h u$ 虎. The first example takes place in the phrase “hu lang shizi” (愿狼師[獅] 子); the second example in the phrase “shanhu hupo jin yin" (珊瑚 震[琥]珀金銀) (Sun Baowen 2012, pp. 6, 29). ${ }^{11}$ As these two phrases consist of only general nouns, there is no any other way to read them otherwise than the following interpretation. The first phrase refers to three ferocious beasts, $h u$ (唐) for 'tiger', lang for 'wolf', and shizi for 'lion'; the second phrase to four expensive matters, shanhu for 'coral', hupo (震 [琥]珀) for 'amber', jin for 'gold', and yin for 'silver'.

The third reason is that Shanjianlü was sanctioned by the Tang court. This is suggested by the stringent quality control of its production. According to the colophon, the manuscript was written on seven pieces of paper by a professional scribe, Guo Quan 國詮, on "the tenth day of the twelfth month in the twenty-second year of the Zhenguan reign” (貞觀廿二年十二月十日, December 29th, 648) (Idem, p. 31). The text was then proofread first by Dao Yi道嶷 and then by Fa Lun 法倫, two Buddhist monks from two different monasteries. After editing, these loose pieces were bound by a professional called Fu Wenkai 輔文開. Moreover, each procedure seems to have been witnessed by government representatives. As stated by the colophon, the production was supervised by four officials, Ma Renyi 馬仁義, Zhao Mu 趙模, Lu Zhengchen 盧爭臣, and Wei Dan 蔚丹, while the whole project was overseen by Yan Liben 閻立本, a top court official who was also a well-known calligrapher and painter. Given such rigorous quality control, the making of this manuscript was unquestionably serious court business. The manuscript was most probably intended to be read by Emperor Tang Taizong. In short, this Buddhist source was produced with the highest possible standards, including the name taboo practice.

In addition, Chinese historical accounts document that $h u$ should be avoided, because the name bearer $\mathrm{Li} \mathrm{Hu}$ was posthumously elevated to emperor. According to Tanghuiyao, Li Yuan, one month after he took the throne, created Li Hu "Jing Emperor" (景皇帝) and placed his name tablet in the ancestral temple for worship (Wang $\mathrm{Pu} 961 / 1955$, p. 1). Probably because of the influence of the ancestral worship, $h u$ remained widely tabooed throughout the Tang dynasty. For example, it was often replaced by $w u$ 武 - the phrase hupi 虎皮, the official position huben 虎賁, and the geographic name hulao 虎牢 were changed into wupi 武皮, wuben 武賁, and wulao 武牢, respectively. ${ }^{12}$

Finally, forms similar to the above two examples have been identified as quebi taboos of $h u$. Soymié (1990, p. 404) discusses four forms: 虎 (P.2530), 居 (P.3371), 虏(P.2717), and (P.2717). Dou Huaiyong (2010, pp. 220-221) finds many more illustrations. From manuscript P.2457 alone, for instance, he recognises these two forms:

\footnotetext{
${ }^{10}$ For more information, visit the official website http://www.dpm.org.cn/collection/hand writing/231479.html.

${ }_{11}^{11}$ This manuscript can be easily found on the Internet.

${ }^{12}$ For more examples, see Adamek (2015, pp. 52, 236, 238, 273), Wang Jian (2011, pp. 199 203), and Wang Yankun (2009, pp. 103-117).
} 
虔 and 僧. The first and second forms examined by the two scholars are exactly the same as our first and second examples.

Arguably, the two examples discussed are quebi taboos of $h u$. They were deliberately written by the scribe to deviate from the orthodox orthography. As no other earlier examples have been confirmed, we can claim that the quebi method might have been introduced during Tang Taizong's reign or at a certain time between 626 and 648 .

\section{Implications}

We should abandon the traditional view that quebi first appeared during Tang Gaozong's reign. This view does not hold. The earliest examples it rests upon are not the earliest usage of quebi. There are a number of earlier examples dated to Tang Gaozong's reign. At this stage of research, the quebi method, as far as unequivocal examples can be demonstrated, first appeared during Tang Taizong's reign or at a certain time between 626 and 648. Therefore, we have to reassess the common knowledge about how bihui developed in the early 7 th century.

In addition, the argument of this paper has wider implications. Taboo examples, especially those concerned with the Chinese emperors' names, can be accurately traced back to some known persons. The results of this study, therefore, can allow us to better use taboos in our research. Given the limits, this paper draws two implications regarding the examination of chronology and authenticity.

When determining the authenticity of a pre-7th-century Chinese source, the general guidance should be: if it employs quebi to taboo a name, its authenticity should be treated with great care. No source might be made earlier than the appearance of any applied method.

As for dating the sources, the general instruction is: if a document employs only the quebi method to avoid the characters bing 是, bing 丙, $h u$ 虎, yuan 淵, shi 世, and/or $\min$ 民, it seems to have been produced earlier than we commonly believe. Its terminus post quem could be Tang Taizong's reign instead of Tang Gaozong's reign.

Admittedly, although our new theory and instructions may be enhanced when more sources are brought to light, the traditional view initiated in 1928 should be discarded. It is now certain that quebi appeared earlier than Tang Gaozong's reign. It was already used in 648 .

\section{References}

Academia Sinica. The Sino-Western Calendar Transfer Program. http://sinocal.sinica.edu.tw/. Retrieved on July 5th, 2017.

Adamek, Piotr (2015): A Good Son is Sad if He Hears the Name of His Father: The Tabooing of Names in China as a Way of Implementing Social Values. Leeds, Maney Publishing.

Beijing tushuguan jinshizu 北京圖書館金石組 (1997): Beijing tushuguan cang zhongguo lidai shike taben huibian (di shiyi ce, Tang) 北京圖書館藏中國歷代石刻拓本匯編第十一冊唐 [Col- 
lections of ancient Chinese stone rubbings, Vol. 11, Tang]. Zhengzhou, Zhongzhou guji chubanshe.

Chen Yuan 陳垣 (1928): Shihui juli 史諱舉例 [Name taboos in history]. Yenching Journal of Chinese Studies 燕京學報 No. 4, pp. 537-651.

Chen Yuan 陳垣 (1958): Shihui juli 史諱舉例 [Name taboos in history]. Beijing, Kexue chubanshe.

Dou Huaiyong 竇懷永 (2010): Dunhuang wenxian bihui yanjiu 敦煌文獻避諱研究 [A study of name taboo in Dunhuang manuscripts]. Lanzhou, Gansu jiaoyu chubanshe.

Soymié, Michel (1990): Observations sur les Caractères Interdits en Chine. Journal Asiatique Vol. 278, Nos 3-4, pp. 377-407.

Sun Baowen 孫寶文 (2012): Guancang guobao moji-Guoquan shu Shanjianlü 館藏國寶墨跡·國 詮書善見律 [National treasures and calligraphies in the Palace Museum: Shanjianlü composed by Guo Quan]. Shanghai, Shanghai cishu chubanshe.

The Palace Museum. http://www.dpm.org.cn/collection/handwriting/231479.html. Retrieved on July 5th, 2017.

Wang Jian 王建 (2011): Shihui cidian 史諱辭典 [A dictionary of name taboos]. Shanghai, Shanghai guji chubanshe.

Wang Pu 王溥 (961/1955): Tanghuiyao 唐會要 [Institutional history of the Tang dynasty]. Beijing, Zhonghua shuju.

Wang Yankun 王彥坤 (2009): Lidai bihuizi huidian 歷代避諱字彙典 [A collection of name taboos]. Beijing, Zhonghua shuju.

Zhang Hengjun 張恒俊 (2003): Chen Yuan yu bihuixue 陳垣與避諱學 [Chen Yuan and studies of name taboos]. Around Southeast Asia 東南亞縱横 No. 6, pp. 77-79.

Zhu Luchuan 朱露川 (2015): Chen Yuan “Shihui juli” de sixiang, jiegou he fangfalun yiyi 陳垣 《史諱舉例》的思想、結構和方法論意義 [Contributions of Chen Yuan's Name Taboos in History: Rationale, structure and methodology]. Academic Research 學術研究 No. 10, pp. $106-110 \& 160$. 
